\title{
PENDIDIKAN LINGKUNGAN HIDUP MELALUI MEDIA KONTEKSTUAL BERBANTUAN INFORMATION COMPUTER TECHNOLOGY (ICT) BAGI ANAK DIDIK DAN ORANG TUA
}

\author{
Rosanti $^{1}$, Rika Anggela ${ }^{2}$, Rina $^{3}$ \\ 1,2,3Program Studi Pendidikan Geografi, Fakultas Ilmu Pendidikan dan Pengetahuan Sosial IKIP \\ PGRI Pontianak, Jalan Ampera Nomor 88 Pontianak \\ 1e_mail :rosanti-30@yahoo.co.id
}

\begin{abstract}
Abstrak
Tujuan dalam pengabdian masyarakat ini adalah memberikan Pendidikan Lingkungan Hidup Melalui Media Kontekstual Berbantuan Information Computer Technology (ICT) bagi Anak didik dan orang tua. Metode yang digunakan dalam pengabdian ini adalah survei lapangan dan Tindakan. Survei lapangan dilakukan dengan mendatangi lokasi, berkoordinasi dengan Ketua RW dan Pengelola Rumah Baca Muzakir. Tindakan yang dilakukan adalah pengadaan Alat, Bahan, dan Materi Pendidikan Lingkungan Hidup melalui Media Kontekstual berbantuan ICT di Rumah Baca Masyarakat Gang H. Hasan kota Pontianak dapat dilihat bahwa pelaksanaan telah sesuai dengan tujuan yang ingin dicapai. Tercapainya tujuan pengabdian ini terlihat dari dokumentasi berupa berita acara dan absen kehadiran, serta foto kegiatan yang menunjukkan antusias ibu dan anak serta warga di lingkungan Rumah Baca Muzakir.
\end{abstract}

Kata Kunci: Pendidikan Lingkungan Hidup, Media Kontekstual, ICT

\begin{abstract}
The aim of community service is to provide environmental education through ICTassisted contextual media for students and parents in Muzakir Reading House. The method used in this service is the field survey and Action. The field survey was conducted by visiting the location, coordinating with the Head of $R W$ and the Manager of Muzakir Reading House. The action taken is the procurement of Tools, Materials, and Materials for Environmental Education through ICT-assisted Contextual Media at the Reading Hall of the H. Hasan Community in Pontianak city. It can be seen that the implementation is in accordance with the objectives to be achieved. The achievement of the PKM objectives is evident from the documentation in the form of a letter of assignment that was endorsed by local officials, minutes and attendance absences, as well as photos of ongoing activities that show the enthusiasm of mothers and children as well as residents in the Muzakir.
\end{abstract}

Keywords: Environmental Education, Contextual Media 


\section{PENDAHULUAN}

Masalah lingkungan menjadi fokus utama dalam perkembangan dunia sekarang ini. Permalahan Lingkungan identik dengan adanya hubungan kehidupan manusia dengan ekologi. Soerjani (2009) menyatakan bahwa masalah kehidupan sebagian timbul karena ulah manusia seperti pencemaran sungai oleh industri, penumpukan limbah sumber daya yang tersia-sia di pasar-pasar dan rumah”. Satu diantara permasalahan yang kerap kali muncul serta belum bisa maksimal diselesaikan sampai saat ini ialah pencemaran Sungai Kapuas oleh limbah domestik pemukiman dan aktivitas perdagangan dan jasa, limbah industri besar dan kecil, keramba ikan dan limpasan perkotaan (Purnaini, 2017).

Sungai Kapuas menjadi tempat yang sangat rawan dijadikan tempat praktis dalam mencemari lingkungan. Dimana kebiasaan utama masyarakat mulai dari anak-anak bahkan orang tua membuang sampah atau limbah rumah tangga langsung ke sungai, dan itu sudah menjadi hal yang biasa bagi. Perilaku tersebut menjadi kebiasaan yang secara tidak disadari menjadi budaya selama ini. Untuk mengubah sikap dan perilaku tersebut maka perlu adanya pendidikan lingkungan hidup. Pendidikan lingkungan hidup merupakan pembelajaran yang dilakukan untuk membantu seseorang atau sekelompok masyarakat dalam memahami lingkungan hidup dengan tujuan akhir untuk meningkatkan perlindungan dan sikap bertanggung jawab terhadap lingkungan hidup.

Hubungan tersebut diwujudkan dengan sikap dan perilaku masyarakat dalam pengelolaan lingkungan pada kehidupan sehari-hari. Sikap yaitu suatu reaksi dari suatu perangsang atau situasi yang dihadapi. Ungkapan demikian akan memunculkan perilaku masyarakat yang berwawasan lingkungan, sedangkan perilaku yang dimaksud ialah tindakan yang dilakukan seseorang dalam memanfaatkan lingkunganananya, yang diwujudkan dengan dampak baik positif maupun negatif. Sikap dan Perilaku yang positif pastinya itu yang pada dasarnya diinginkan oleh berbagai kalangan masyarakat bahkan instansi pemerintahan. Sikap dan perilaku yang positif dalam mengelola lingkungan hidup sangatlah penting bagi seluruh masyarakat, namun hal yang paling utama harus dicapai ialah 
menanamkan sikap dan perilaku peduli lingkungan hidup yang dimulai sejak dini atau anak-anak.

Seyogyanya pendidikan apapun itu dimulai dari lingkungan keluarga. Melalui keluarga, maka sikap dan perilaku dalam sehari-hari akan dterapkan dimanapun seseorang berada. Begitu pula dengan pendidikan lingkungan hidup, seharusnya sudah dimulai dari dalam keluarga dahulu, namun tidak semua anggota keluarga bisa memiliki pemahaman apalagi sikap dan perilaku tentang pendidikan lingkungan hidup. Mengingat pentingnya Pendidikan Lingkungan Hidup, berbagai instansi pendidikan formal maupun non formal sudah banyak yang memberikan pendidikan tersebut yang dimulai sejak dini. Rumah Baca Muzakir merupakan wadah pendidikan nonformal. Tempat tersebut berada atas di bantaran Sungai Kapuas. Anak didik yang belajar di rumah baca Muzakir dan merupakan generasi penerus dalam masyarakat yang nantiya akan mengelola lingkungan disekitar tempat tinggal. Selain itu, Anak didik yang belajar di tempat tersebut sebagian besar tinggal di bantaran sungai. Tempat tersebut juga memberikan layanan belajar membaca dan menulis serta menghafal Al-Quran kepada anak-anak yang berada di lingkungan tersebut. Untuk itu, rumah baca Muzakir sangat cocok dijadikan sebagai tempat untuk memberikan pendidikan lingkungan hidup yang dimulai sejak dini, terutama bagi anak didik yang belajar di tempat itu. Dalam catatan Direktorat PLS Depdiknas (2006) menyatakan bahwa Taman Bacaan Masyarakat dapat dimanfaatkan sebagi sarana mendapatkan ilmu pengetahuan. Untuk itu rumah baca Muzakir juga dapat digunakan dalam memberikan ilmu pengetahuan khususnya Pengabdian Kepada Masyarakat (PKM )ini.

Tim Dosen Pendidikan Geografi IKIP PGRI Pontianak akan melakukan pengabdian dengan memberikan Pendidikan Lingkungan Hidup berupa pemberian konsep serta contoh yang sesuai dengan keadaan sebenarnya di lingkungan sekitar anak didik melalui media Information Computer Technology (ICT). Hal ini penting karena permasalahan lingkungan yang ada di bantaran Sungai Kapuas merupakan hasil dari akumulasi perilaku manusia yang semakin krusial dan global. Selain itu, PLH merupakan salah satu langkah intervensi dalam pembinaan 
pembentukan perilaku yang bertanggung jawab terhadap lingkungan hidup. Kerusakan alam yang terjadi pada dasarnya lebih dititikberatkan pada kemampuan manusia untuk melihat dengan jangkauan jauh melampaui batas kepentingan sendiri di samping kemampuan dalam melihat kenyataan yang sebenarnya dalam kehidupan (Soerjani, 1997).

Pendidikan lingkungan saat ini sudah diwajibkan dalam kurikulum sekolah, namun belum dapat diimlementasikan secara maksimal oleh seluruh jenjang pelaksana pendidikan, apalagi di tempat bimbingan belajar yang banyak menyebar di berbagai wilayah. Untuk itu, Tim pengabdian memberikan pendidikan yang sama pada anak didik serta orang tua yang belajar di Rumah Baca Muzakir tersebut. Mengingat pentingnya peran orang tua sebagai panutan/contoh bagi anak-anak dalam keluarga untuk memberian pemahaman tentang lingkungan hidup, maka Tim Pengabdian mengadakan kegiatan dan mengundang anak didik beserta orangtua untuk bersama-sama belajar tentang Pendidikan Lingkungan Hidup. PKM yang dimaksud ialah ingin memberikan; "Pendidikan Lingkungan Hidup Melalui Media Kontekstual Berbantuan ICT bagi orang Tua dan anak yang berada di Rumah Baca Muzakir"

\section{METODE}

Metode pelaksanaan Pendidikan Lingkungan Hidup melalui Media Kontekstual berbantuan ICT Gang H. Hasan Kota Pontianak menggunakan Survei dan Tindakan. Metode tersebut akan dijelaskan pada bagian berikut ini:

\section{Survei Lapangan}

Dalam pelaksanaan survei, seluruh tim melaksanakan tahapan berikut ini: (a) Survei lapangan langsung mendatangi Kepala Rukun Warga (RW) dan Pengelola Rumah Baca Muzakir (Bapak Efrizar dan Ibu Yulida), Jln. Adi Sucipto, Gang H. Hasan Kota Pontianak. Hal ini bertujuan untuk mendapatkan informasi kegiatan yang sering dilakukan di daerah tersebut serta sekaligus meminta izin mengadakan PKM di tempat tersebut. (2) Koordinasi dengan pihak Rumah baca Muzakir dan kepala Rukun Tetangga (RT) untuk menentukan kesepakatan mufakat antara waktu dan tempat pelaksanaan PKM ini. (3) Survei Lapangan 
bertujuan untuk mendapatkan informasi sekaligus memberi informasi tentang serangkaian rencana pelaksanaan program Pengabdian ini yang disampaikan kepada warga masyarakat, anak didik dan orang tua serta masyarakat khususnya Gang H. Hasan Kota Pontianak.

\section{Tindakan (Action)}

Berdasarkan hasil survei, maka tim membuat perencanaan sebagai dasar melaksanakan kegiatan PKM meliputi:

\section{Pengadaan alat dan bahan}

Adapun alat dan bahan, yang dibutuhkan untuk pendidikan lingkungan hidup pada anak didik dan orang tua di Gang H. Hasan Kota Pontianak sebagai berikut:

Alat

: $\quad$ Laptop, Proyektor/Infocus, Layar proyektor, Sound Sistem, Mikropon, Materi berbantukan ICT (Power point).

Bahan Kertas A4, Tinta Printer.

Sumber Baca Ringkasan Materi Pendidikan Lingkungan Hidup. Cara Kerja : Merancang dan membuat materi pendidikan lingkungan hidup secara kontekstual menggunakan microsoft powerpoint melalui laptop serta membuat ringkasan materi dalam bentuk hardcopy atau di print menggunakan kertas dan di bagikan kepada anak didik beserta orang tua.

\section{Pelaksanaan Program}

Pelaksanaan yang dilakukan seluruh Tim dalam kegiatan ini berupa penyampian konsep dan contoh pendidikan lingkungan hidup secara kontekstual berbantuan ICT kepada anak didik dan orang tua di rumah baca Muzakir.

\section{HASIL DAN PEMBAHASAN}

Kegiatan pengabdian kepada masyarakat (PKM) dengan judul "Pendidikan Lingkungan Hidup Melalui Media Kontekstual Berbantuan Information Computer Technology (ICT) bagi Anak didik dan orang tua". PKM ini dilakasanakan di 
Rumah Baca Muzakir yang berdiri di bantaran Sungai Kapuas yang sasarannya untuk memberi pemahaman tentang lingkungan hidup kepada masyarakat sekitar yang diwakili oleh anak didik dan orangtua. Adapun Pelaksanaan Program PKM dideskripsikan sebagai berikut.

\section{Pemberian materi Lingkungan Hidup melalui Media kontekstual berbantuan ICT}

Materi yang diberikan berupa penjabaran terhadap permasalahan lingkungan yang sedang terjadi di Indonesia dalam skala besar dan secara spesifik di daerah Pontianak yang kaitannya dengan pencemaran Sungai Kapuas. Materi yang diberikan didukung dengan media ICT berupa Laptop, LCD dan Proyektor. Penggunaan media ini membantu masyarakat untuk memahami kondisi lingkungan hidup di sekitar sesuai dengan keadaan sebenarnya. Pelaksanaan program ini mendapat respon yang positif dari anak didik dan orangtua. Terlihat dari peserta PKM yang turut aktif bertanya dan memberikan pendapatnya berkaitan dengan kondisi lingkungan di sekitar rumah.

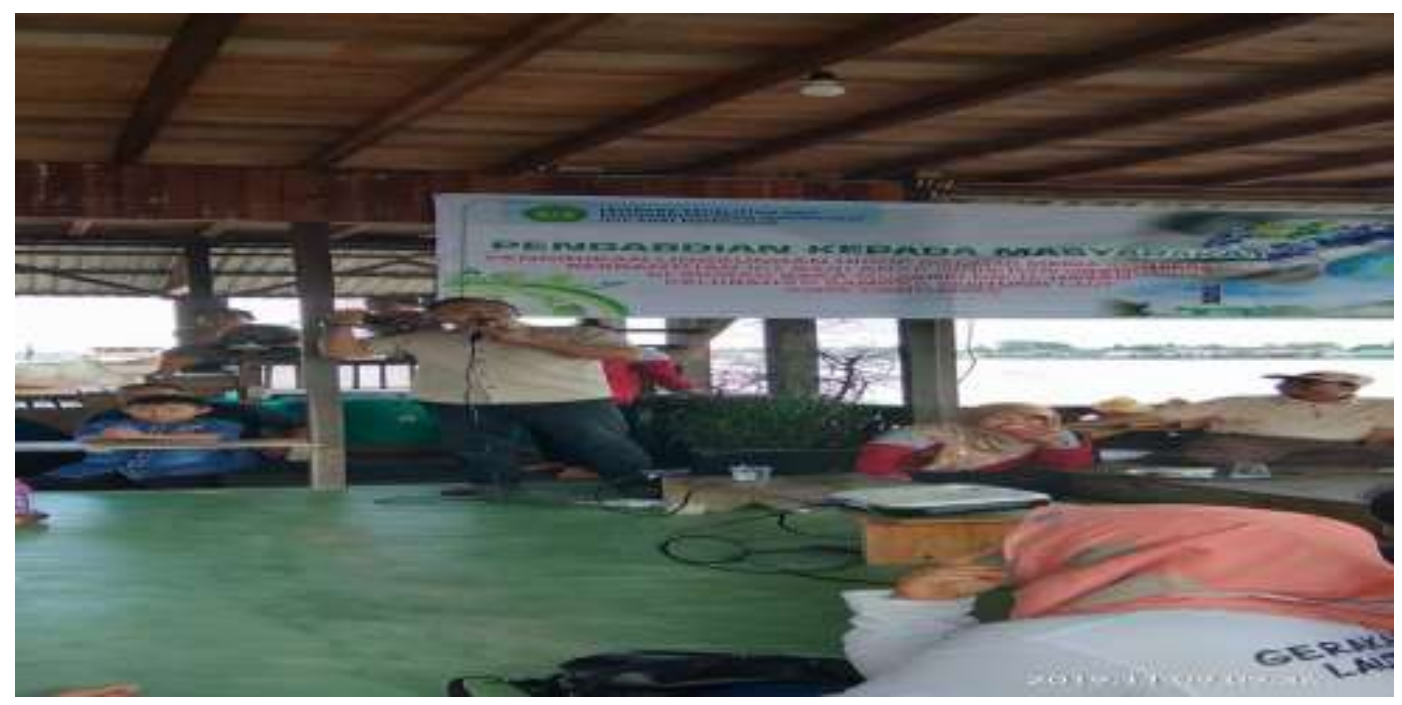

Gambar 1. Penyampaian Materi Pendidikan Lingkungan

Hidup melalui Media ICT berbasis Kontekstual

\section{Penyuluhan Tentang Daur Ulang Sampah}

Penyuluhan yang diberikan oleh Tim PKM beserta Bank Sampah Rosella ini menggunakan metode demontrasi. Kegiatan ini dimulai dengan pengenalan 
sampah yang masih memiliki nilai ekonomis. Selanjutnya pengenalan hasil dari pengelohan sampah yang berbentuk barang-barang rumah tangga yang bernilai ekonomi tinggi seperti : tempat tisu, celengan, keset kaki, wadah minuman, tas, dll.

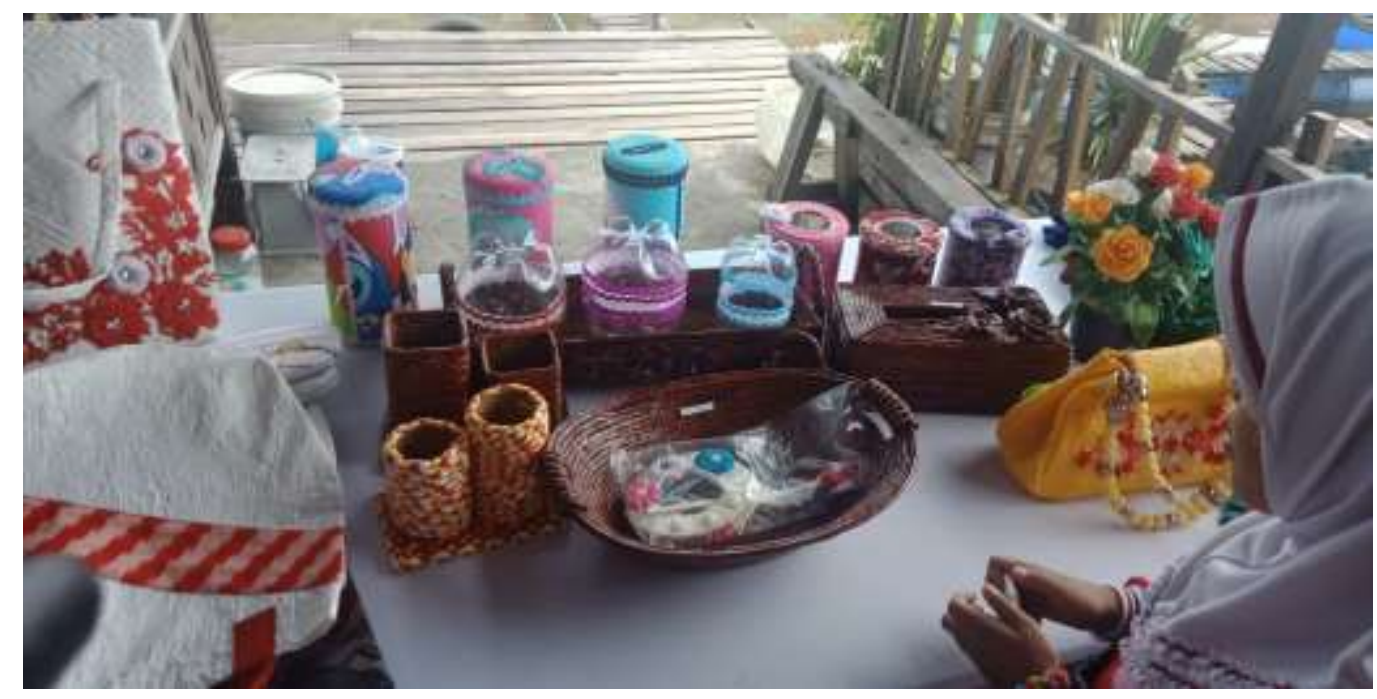

Gambar 2. Contoh barang dari daur ulang sampah

\section{Pemberian Pertanyaan untuk Evaluasi Pemahaman terhadap Materi}

Materi yang diberikan sudah tersampaikan dengan baik. Langkah selanjutnya adalah pemberian pertanyaan yang berkaitan dengan materi tersebut sebagai evaluasi pemahaman peserta terhadap permasalahan lingkungan. Semua peserta pada kenyataanya dapat memahami materi yang terlihat dari jawaban yang peserta sampaikan. Peserta yang dapat menjawab mendapat bingkisan menarik. 


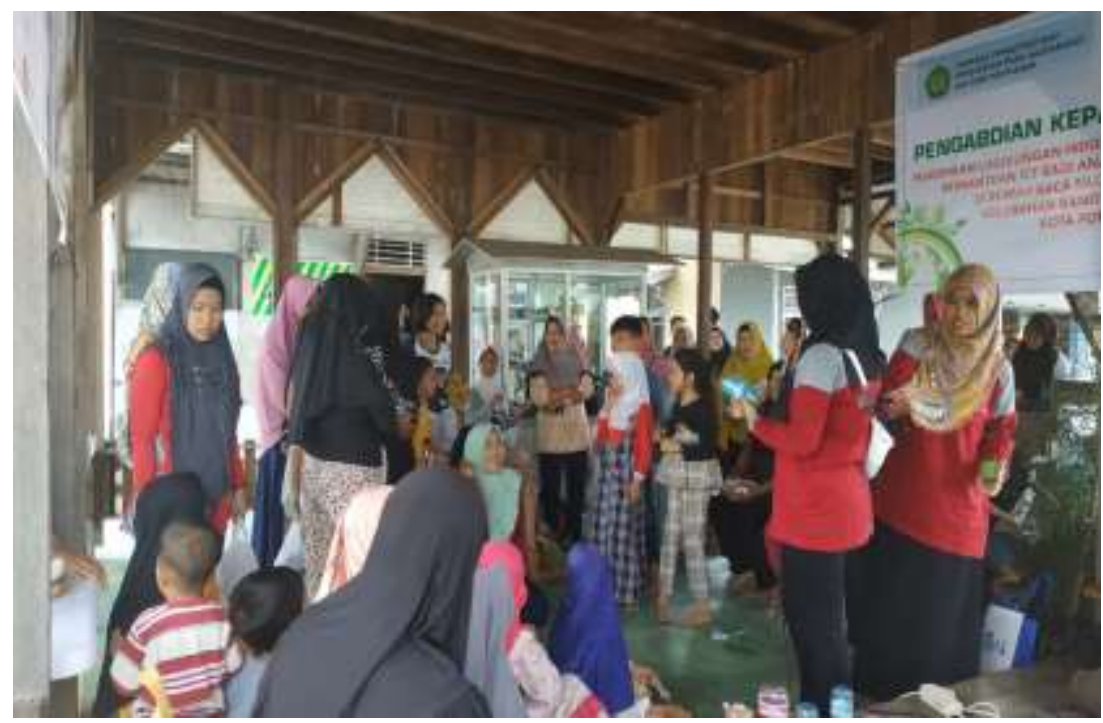

Gambar 3. Sesi Tanya Jawab tentang pemahaman materi Pendidikan Lingkungan Hidup

\section{SIMPULAN}

Berdasarkan kegiatan yang telah dilaksanakan, maka dapat disimpulkan bahwa kegiatan Pengabdian kepada Masyarakat yang telah dilaksanakan oleh Prodi Pendidikan Geografi berjalan dengan lancar sesuai dengan target dan luaran yang telah direncanakan. Segala aktivitas yang meliputi pemberian materi tentang lingkungan hidup, penyuluhan daur ulang sampah dan evaluasi pemahaman peserta terlaksana dengan baik. Kegiatan yang dilaksanakan memberikan gambaran bahwa kegiatan ini membawa pengetahuan dan kesadaran terhadap lingkungan.

\section{UCAPAN TERIMA KASIH}

Terimakasih kami ucapkan kepada Rektor IKIP PGRI Pontianak, Kepala Lembaga Penelitian dan Pengabdian Kepada Masyarakat, Inisiator (Efrizar dan Yulida) yang telah membantu dalam merintis rumah baca masyarakat di jalan $\mathrm{H}$. Hasan Kota Pontianak. 


\section{DAFTAR PUSTAKA}

Depdinas. (2006). Panduan penyelenggaraan taman bacaan masyarakat. Jakarta : Direktorat Jenderal Lembaga Pendidikan Luar Sekolah.

Purnaini, R. (2017). Kualitas air sungai kapuas kecil bagian hilir pada kondisi pasang dan surut. Artikel: Seminar Nasional Penerapan Ilmu Pengetahuan dan Teknologi 2017 (Buku 3 (Bidang Lingkungan Binasan dan Rekayasa)).

Soerjani, M. (1997). Sustainabel industrial technology with environmental outlook. science, problems and enviromental manajemen. Jakarta: Institute For Environmental Education and Development. 